\title{
STUDI ANALISIS KUALITAS AIR SUNGAI BAH BIAK KOTA PEMATANGSIANTAR
}

\section{(Analytical Studies of River Water Quality of Bah Biak Pematangsiantar City)}

\author{
Ewin Handoco \\ Jurusan Manajemen Pengelolaan Sumberdaya Perairan, Fakultas Teknik dan Pengelolaan Sumberdaya Perairan, \\ Universitas HKBP Nommensen Pematangsiantar \\ ewinhandoco@gmail.com
}

\begin{abstract}
ABSTRAK: Tingginya aktivitas masyarakat di sempadan Sungai Bah Biak menyebabkan pencemaran di perairan sungai tersebut. Peningkatan jumlah pemukiman dan industri di Kota Pematangsiantar tentu berdampak kepada kualitas perairannya. Tujuan penelitian ini adalah untuk mengetahui kualitas air sungai Bah Biak di Kota Pematangsiantar meliputi parameter fisik dan kimia perairan. Penelitian ini dilakukan pada tahun 2021 di Sungai Bah Biak Kota Pematangsiantar. Pengambilan sampel air di Sungai Bah Biak dilakukan dengan tiga kali pengulangan yaitu pada bulan Maret, Juni dan Agustus dengan mempertimbangkan keterwakilan musim. Pengambilan sampel air dilakukan secara insitu untuk parameter kecerahan, $\mathrm{pH}$, total dissolved solid (TDS), daya hantar listrik, suhu dan dissolved oxygen (DO), ammonia, sedangkan untuk pengukuran skala laboratorium dilakukan untuk parameter biologycal oxygen demand (BOD) dan chemical oxygen demand (COD). Hasil pengukuran akan ditampilkan dalam bentuk grafik dan dibahas seacara deskriptif dengan merujuk pada baku mutu yang ditetapkan. Berdasarkan hasil pengukuran beberapa parameter kualitas air di Sungai Bah Biak maka dapat disimpulkan bahwa mayoritas parameter yang diteliti masih memenuhi baku mutu namun terdapat parameter yang telah melewati ambang baku mutu yaitu parameter BOD dan ammonia.
\end{abstract}

Kata Kunci: kualitas air, aktivitas masyarakat, pencemaran, baku mutu, Sungai Bah Biak

\begin{abstract}
High community activity on the border of the Bah Biak River causes pollution in the waters of the river. The increase in the number of settlements and industries in Pematangsiantar City certainly has an impact on the quality of its waters. The purpose of this study is to find out the water quality of the Bah Biak River in Pematangsiantar City covering the physical and chemical parameters of the waters. This research was conducted in 2021 in Bah Biak River Pematangsiantar City. Water sampling in the Bah Biak River is carried out with three repetitions, namely in March, June and August taking into account the representation of the seasons. Water sampling is carried out in situ for parameters of brightness, $\mathrm{pH}$, total dissolved solid (TDS), electrical delivery, temperature and dissolved oxygen (DO), ammonia, while for laboratory scale measurements are carried out for biologycal oxygen demand (BOD) and chemical oxygen demand (COD) parameters. The results of the measurement will be displayed in graphic form and descriptively discussed by referring to the specified quality standards. Based on the results of measurements of several water quality parameters in the Bah Biak River, it can be concluded that the majority of the parameters studied still meet the quality standards but there are parameters that have passed the quality standard threshold, namely BOD and ammonia parameters.
\end{abstract}

Keywords: water quality, community activities, pollution, quality standards, Bah Biak River 


\section{PENDAHULUAN}

Daerah Aliran Sungai (DAS) Bah Biak merupakan salah satu aliran sungai yang mengalir di Kota Pematangsiantar yang berasal dari empat sungai cukup besar dan memiliki banyak kelokan sungai. Daerah aliran sungai Bah Biak melewati daerah Kecamatan Siantar Marimbun dan Siantar Marihat, Kota Pematangsiantar. Kota Pematangsiantar merupakan salah satu kota yang pembangunannya berkembang pesat. Kota Pematangsiantar juga tentu memiliki resiko kualitas air tercemar yang diakibatkan oleh pengaruh karena kepadatan penduduk, limbah industri, tata ruang yang tidak sesuai dengan peruntukannya dan tingginya eksploitasi sumberdaya air. Berbagai aktivitas tersebut tentunya mengakibatkan penurunan kualitas air pada daerah aliran sungai (Yohannes, $d k k$., 2019; Yogafanny, 2015; Liyanage\&Yamada, 2017).

Perubahan penggunaan lahan yang tidak terkendali dapat menyebabkan menurunnya debit air di musim kemarau atau dapat menyebabkan banjir pada saat musim penghujan (Utami\&Suprayogi, 2014; Permatasari, dkk., 2017). Kualitas lingkungan perlu diperbaiki untuk menjaga keberlanjutan fungsi DAS dengan melestarikan fungsi lahan sebagai daerah tangkapan air melalui arahan penggunaan lahan yang tepat (Notonagoro, $d k k$., 2019). Pengelolaan wilayah pesisir dan laut dapat didekati melalui pengelolaan DAS karena berbicara mengenai daerah aliran sungai artinya mulai dari hulu hingga hilir. Oleh karena itu, aktivitas yang dibangun di wilayah hulu akan berdampak ke wilayah hilir hingga ke pesisir dan laut (Dahuri, 2001; Mustika, 2017). Limbah pemukiman merupakan salah satu bahan pencemar yang dihasilkan oleh daerah pemukiman atau rumah tangga. Daerah aliran Sungai Bah Biak yang melewati Kota Pematangsiantar tentunya juga dimanfaatkan oleh masyarakat sebagai tempat membuang limbah rumah tangga. Limbah yang berasal dari pemukiman berupa sampah organik (kayu, daun dan sisa makanan), dan sampah non organik (plastik, logam, kertas dan sisa bahan bangunan (Marliani, 2014).
Daerah aliran Sungai Bah Biak sebagian besar dimanfaatkan untuk aktivitas domestik, perkebunan dan pertanian yang akan berdampak terhadap kualitas air sungai tersebut. Dampak buruk terhadap DAS tergantung jenis dan sifat bahan pencemarnya. Indikator pencemaran air sungai dapat diamati secara fisik, kimiawi, dan biologi (Idrus, 2014; (Khairuddin, $d k k$., 2016). Beberapa penelitian kualitas air yang telah dilakukan pada sungai khususnya sungai di Kota Pematangsiantar. Penelitian tersebut menunjukan telah terjadi pencemaran dengan beberapa parameter kualitas air telah melebihi baku mutu lingkungan yang ditetapkan (Mannaulina, 2018; Silalahi, 2020). Tujuan penelitian ini adalah untuk mengetahui kualitas air sungai Bah Biak di Kota Pematangsiantar meliputi parameter fisik dan kimia perairan.

\section{METODE PENELITIAN}

Penelitian ini dilakukan pada tahun $2021 \mathrm{di}$ Sungai Bah Biak Kota Pematangsiantar (Gambar 1). Pengambilan sampel air di Sungai Bah Biak dilakukan dengan tiga kali pengulangan yaitu pada bulan Maret, Juni dan Agustus dengan mempertimbangkan keterwakilan musim hujan dan kemarau yang sangat berpengaruh terhadap kualitas iar sungai. Pada setiap pengambilan sampe air di Sungai Bah Biak dilakukan pada bagian hulu kota (daerah Simarimbun), tengah kota (Jalan Melanthon Siregar) dan hilir kota (daerah BP Nauli).

Pengambilan sampel air pada penelitian ini dilakukan secara insitu untuk parameter kecerahan, $\mathrm{pH}$, total dissolved solid (TDS), daya hantar listrik, suhu dan dissolved oxygen (DO), ammonia, sedangkan untuk pengukuran skala laboratorium dilakukan untuk parameter biologycal oxygen demand (BOD) dan chemical oxygen demand (COD). Hasil pengukuran akan ditampilkan dalam bentuk grafik dan dibahas seacara deskriptif dengan merujuk pada Peraturan Pemerintah Nomor 22 Tahun 2021 Tentang Penyelenggaraan Perlindungan dan Pengelolaan Lingkungan Hidup. 


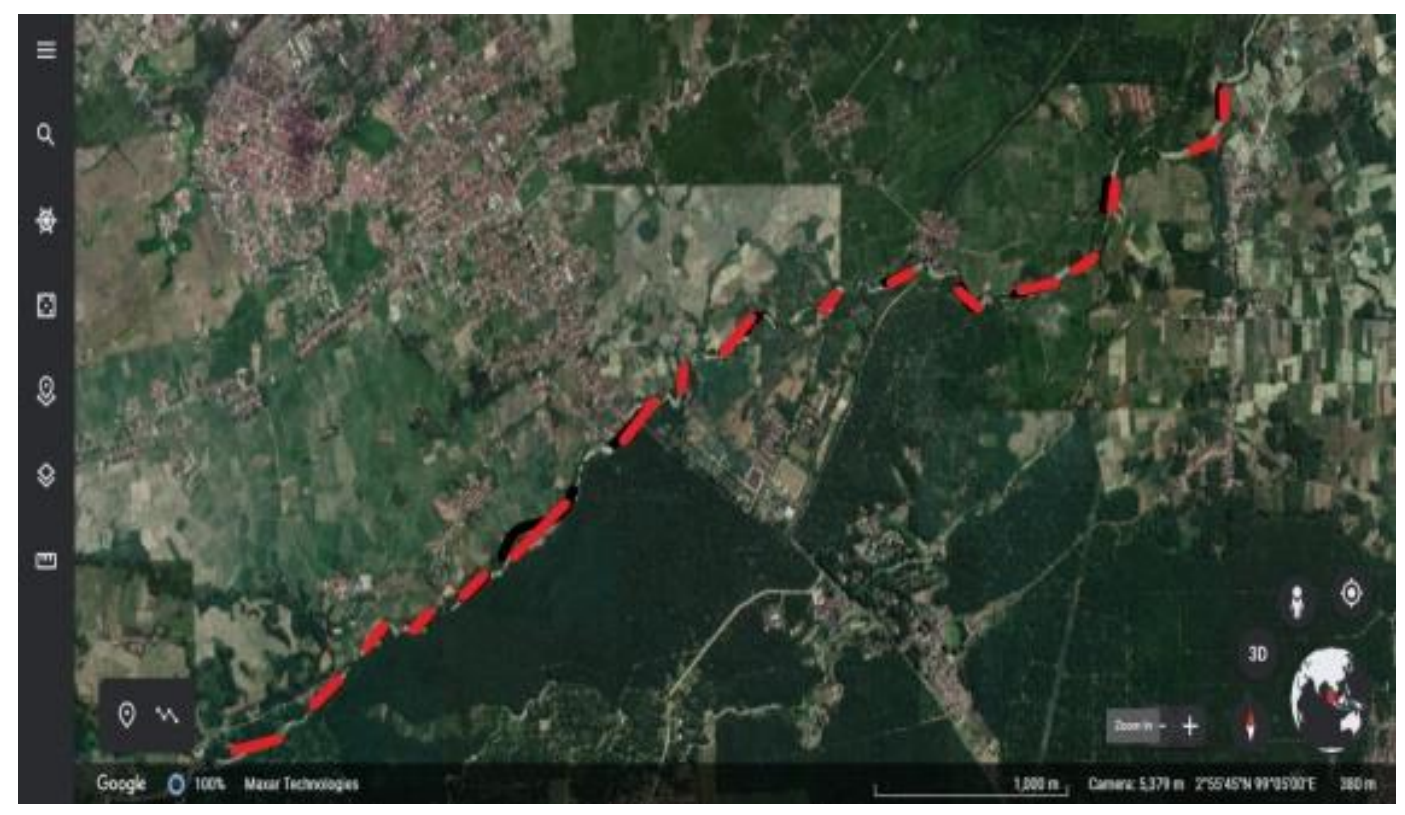

Gambar 1. Peta lokasi penelitian

\section{HASIL DAN PEMBAHASAN}

\section{Kualitas Parameter Fisik Sungai Bah Biak \\ - Suhu}

Suhu memegang peranan penting terkait proses-proses kimia dan biologi organisme di suatu perairan (Sihombing, 2018; Sugianti\&Astuti, 2018). Berdasarkan hasil penelitian diperoleh nilai suhu cenderung fluktuatif, namun perubahannya tidak terlalu signifikan, dengan nilai suhu terendah $28,9^{0} \mathrm{C}$ dan tertinggi $30,3^{\circ} \mathrm{C}$ (Gambar 2).

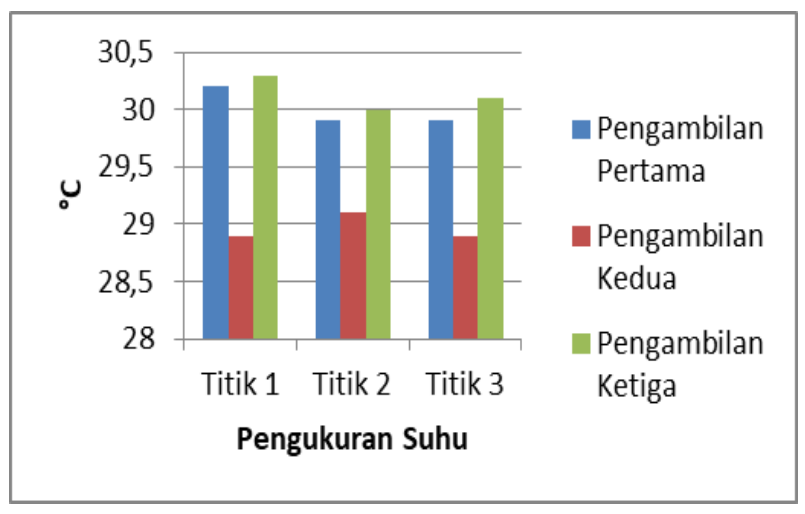

Gambar 2. Hasil pengukuran suhu

Pengamatan di sekitar wilayah Sungai Bah Biak ditemukan telah berkurangnya pohon yang dapat melindungi sungai dari paparan sinar matahari. Sesuai dengan penelitian kualitas air sebelumnya yang menyatakan pola temperatur ekosistem air dipengaruhi oleh berbagai faktor seperti: intensitas cahaya matahari, pertukaran panas antara air dengan udara sekelilingnya, ketinggian geografis, dan juga faktor tutupan canopy (penutupan oleh vegetasi) dari pepohonan (Effendie, 2003; Sanger, $d k k$., 2016; Pratiwi, dkk., 2017). Jika dirujuk dengan baku mutu air sungai berdasarkan PP nomor 22 tahun 2021, maka nilai suhu perairan Sungai Bah Biak termasuk kategori normal karena tidak adanya perbedaan dengan suhu udara di atas permukaan air.

\section{- Kecerahan}

Kecerahan perairan menunjukkan kemampuan cahaya untuk menembus lapisan air pada kedalaman tertentu. Tingkat kecerahan pada perairan alami berkaitan erat dengan aktivitas fotosintesa dan produksi primer. Parameter kecerahan sangat dipengaruhi oleh partikel-partikel terlarut dalam lumpur. Semakin banyak partikel atau bahan organik terlarut maka kekeruhan akan meningkat (Mainassy, 2017). Kekeruhan atau konsentrasi bahan tersuspensi dalam perairan akan menurunkan efisiensi makan dari organisme (Sembiring, 2008).

Beberapa hasil penelitian menunjukan variasi kecerahan air pada Sungai Bah Biak adalah 95-125 cm. Pengukuran kecerahan dilakukan saat siang hari dan dalam kondisi cuaca cerah. Hasil pengukuran kecerahan diperoleh anrtara 32-35 cm (Gambar 3). Penyebab rendahnya tingkat kecerahan pada 
Sungai Bah Biak dikarenakan adanya bahan organik dan non organik terlarut dalam air seperti lumpur, pasir dan sampah khususnya sampah organik yang dapat terurai.

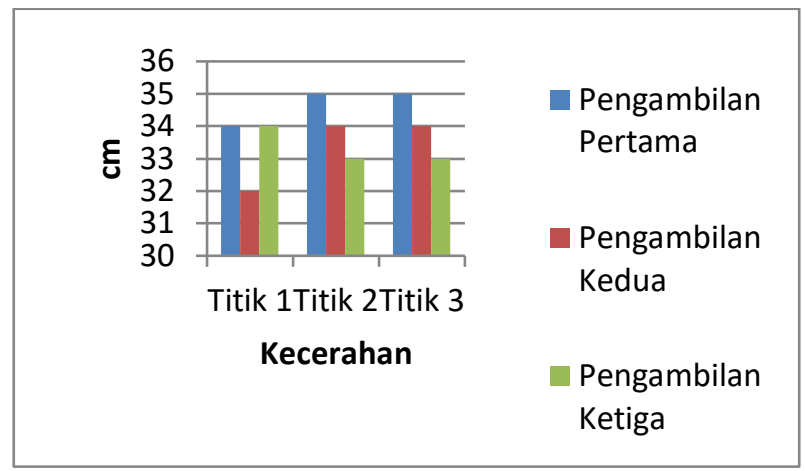

Gambar 3. Hasil pengukuran kecerahan

\section{- Total Dissolved Solid (TDS)}

Berdasarkan hasil pengukuran TDS diperoleh nilai terendah $56 \mathrm{mg} / \mathrm{l}$ dan tertinggi 76 $\mathrm{mg} / \mathrm{l}$ (Gambar 4). TDS atau padatan terlarut ini terdiri dari senyawa organik maupun anorganik di suatu perairan. Teridentifikasi beberapa senyawa anorganik yang terlarut dalam air seperti deterjen dan shampoo yang merupakan limbah cair yang berasal dari rumah tangga atau pemukiman di sekitar Sungai Bah Biak. Padatan yang terlarut di dalam air berupa bahan-bahan kimia anorganik dan gas-gas yang terlarut. Air yang mengandung jumlah padatan melebihi batas menyebabkan rasa yang tidak enak, menyebabkan mual, penyebab serangan jantung (cardiacdisease) dan (tixaemia) pada wanita hamil (Effendi, 2003). Sesuai baku mutu air menurut PP No.22 Tahun 2021 bahwa TDS untuk Kelas 2 adalah $1.000 \mathrm{mg} / \mathrm{l}$ sehingga nilai TDS di Sungai Bah Biak masih berada di bawah nilai baku mutu yang ditetapkan.

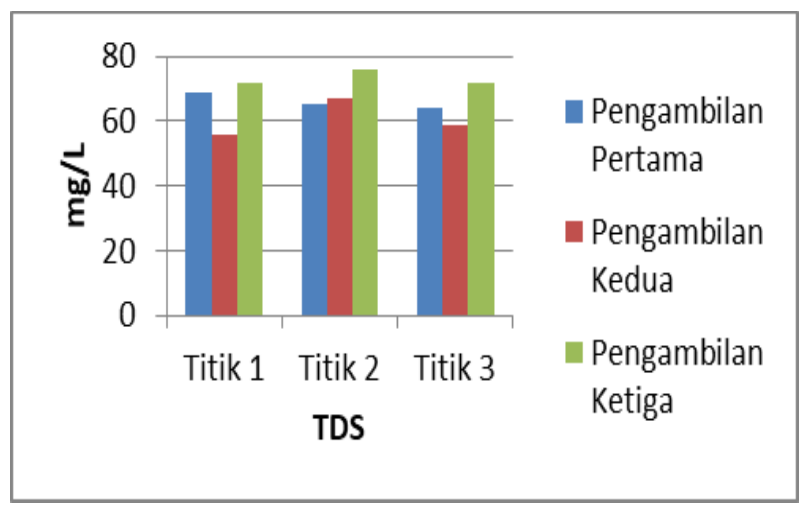

Gambar 4. Hasil pengukuran TDS

\section{- Daya Hantar Listrik (DHL)/EC}

Pengukuran daya hantar listrik bertujuan untuk mengukur kemampuan ion-ion dalam air untuk menghantarkan listrik serta memprediksi kandungan mineral dalam air seperti sodium chloride dan potassium chloride. (Gasim, et al., 2015; Khairunnas\&Gusman, 2018). Konduktivitas air dinyatakan dalam satuan mhos/cm atau Siemens/cm. Umumnya, air tanah dangkal mempunyai harga 30-2000 $\mu \mathrm{mhos} / \mathrm{cm}$.

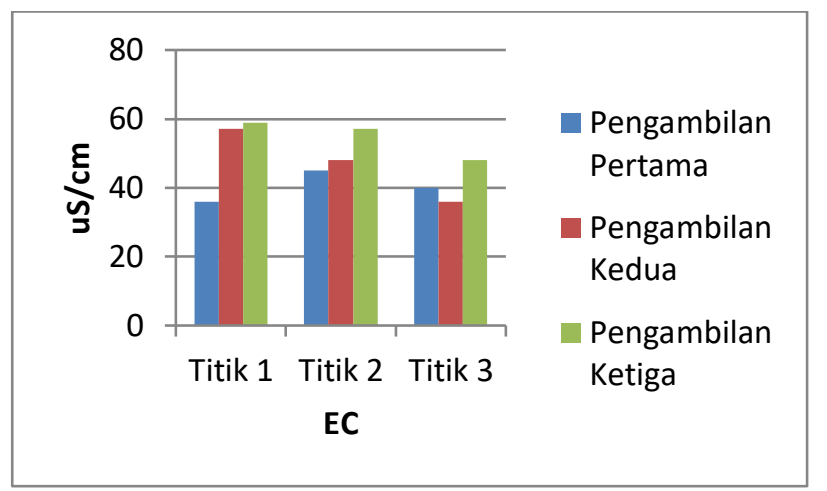

Gambar 5. Hasil pengukuran DHL

Konduktivitas air murni berkisar antara 0$200 \mu \mathrm{S} / \mathrm{cm}$ (low conductivity), konduktivitas sungai-sungai besar/major berkisar antara 200$1000 \mu \mathrm{S} / \mathrm{cm}$ (midrange conductivity), dan air saline adalah 1000-10000 $\mu \mathrm{S} / \mathrm{cm}$ (high conductivity). Nilai konduktivitas untuk air layak minum berkisar antara $42-500 \mu \mathrm{mhos} / \mathrm{cm}$. Nilai konduktivitas lebih dari $250 \mathrm{mhos} / \mathrm{cm}$ tidak dianjurkan karena akan mengendap dalam tubuh dan merusak batu ginjal (Gasim, et al., 2015).

Hasil pengukuran diperoleh DHL berada pada kisaran 36-59 us/cm (Gambar 5), artinya air tersebut sangat rendah daya hantar listriknya. Hal ini dapat terjadi karena tidak banyaknya garam dalam air sehingga konsentrasi ion dalam air sangat rendah. Konsentrasi ion meningkat adalah pada musim kemarau dimana banyak terjadi evaporasi pada badan air.

\section{Kualitas Parameter Kimia Sungai Bah Biak - $\mathbf{p H}$}

Hasil pengukuran parameter $\mathrm{pH}$ di Sungai Bah Biak diperoleh nilai pH 6,55-6,72 (Gambar 6). Sesuai dengan baku mutu yang ditetapkan khususnya untuk kelas 2 yaitu 6-9, sehingga dapat dikatakan $\mathrm{pH}$ perairan sesuai dengan baku mutu. Penelitian lainnya tentang kualitas air 
Sungai Bah Bolon di Kota Pematangsiantas diperoleh nilai $\mathrm{pH}$ berkisar antara 6,72-6,85 (Silalahi, 2020). Nilai pH berkaitan dengan kadar karbondioksida, artinya semakin tinggi $\mathrm{pH}$ perairan maka semakin rendah karbondioksida di air (Prasetyawan, dkk., 2017). Konsentrasi pH suatu perairan juga dipengaruhi oleh limbah rumah tangga serta limbah pabrik yang berada di sekitar perairan sungai (Pamungkas, 2016).

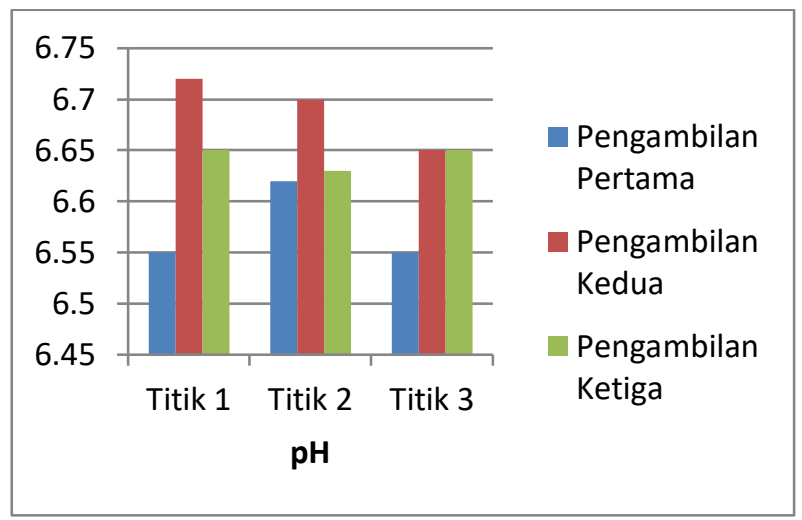

Gambar 6. Hasil pengukuran $\mathrm{pH}$

\section{- Dissolved Oxygen (DO)}

Dissolved Oxygen atau oksigen terlarut sangat diperlukan bagi organisme dalam proses pertumbuhan (Hauer\&Hill, 2007). Oksigen terlarut di perairan berperan penting dalam proses oksidasi dan reduksi sehingga dapat mengurangi beban pencemaran perairan. Okisgen di perairan berasal dari difusi atmosfer dan hasil proses fotosintesa. Berdasarkan baku mutu yang ditetapkan, oksigen terlarut untuk kelas 2 berada pada nilai $4 \mathrm{mg} / \mathrm{l}$. Dengan demikian, nilai DO selama penelitian masih dalam baku mutu namun masih sangat perlu dilakukan pengawasan terhadap pembuangan air limbah baik limbah domestik rumah tangga maupun limbah domestik industri. Nilai oksigen terlarut yang tinggi mencirikan perairan tersebut masih sangat bagus. Selama pengamatan, nilai DO di perairan Sungai Bah Biak berada di antara 6,4-8,3 mg/l (Gambar 7).

Kecepatan arus sungai yang deras menyebabkan permukaan air lebih luas sehingga kesempatan pengambilan oksigen dari udara semakin lebih banyak. Kelarutan oksigen meningkat dengan menurunnya suhu perairan, sedangkan kelarutan oksigen menurun dengan menurunnya tekanan atmosfer. Oksigen di perairan sangat berpengaruh terhadap kehidupan akuatik dan proses biogeokimia. Oksigen dibutuhkan oleh organism akuatik untuk respirasinya (Effendie, $d k k ., 2013$ ). Oksigen terlarut di perairan juga dipengaruhi oleh banyaknya limbah organic yang masuk ke perairan sungai. Hal ini dikarenakan jumlah oksigen yang dibutuhkan oleh bakteri untuk menguraikan bahan organic menjadi bahan anorganik (Simanjuntak, 2007).

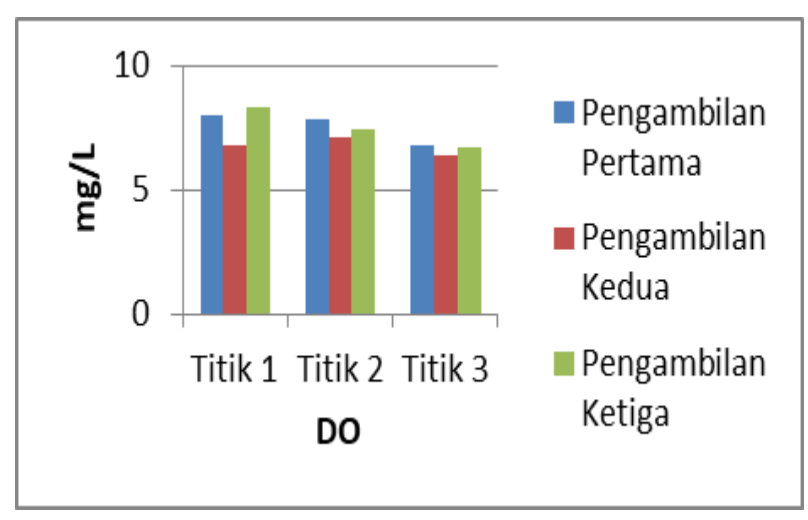

Gambar 7. Hasil pengukuran DO

\section{- Biologycal Oxygen Demand (BOD)}

Semakin besarnya konsentrasi BOD mengindikasikan bahwa perairan tersebut sudah tercemar (Djoharam, dkk., 2018). nilai konsentrasi BOD yang berkisar antara 0-10 mg/l mengindikasikan bahwa perairan tersebut tercemar ringan, nilai BOD yang memiliki konsentrasi antara 10-20 mg/l termasuk kategori pencemaran sedang, sedangkan >25 mg/l dikategorikan tinggi tingkat pencemarannya (Salmin, 2005).

Pada pengukuran nilai BOD didapatkan hasil bahwa nilai konsentrasi BOD di Sungai Bah Biak adalah 4,5 mg/l-6,7 mg/l (Gambar 8). Sesuai dengan pernyataan diatas bahwa perairan tersebut sudah tercemar kategori ringan. Sesuai Baku Mutu Perairan (PP No.22 Tahun 2021 Kelas II) bahwa nilai BOD yang diperbolehkan untuk kelas 2 adalah $3 \mathrm{mg} / \mathrm{L}$, sehingga nilai tersebut sudah tidak memenuhi baku mutu yang ditetapkan. Perlu adanya suatu pengawasan yang dilakukan untuk mengantisipasi pencemaran perairan yang lebih parah. Terlebih daerah yang dilewati sungai ini merupakan daerah yang berkembang pesat, dan arah pembangunan kota cenderung fokus ke daerah sepanjang sungai ini. 


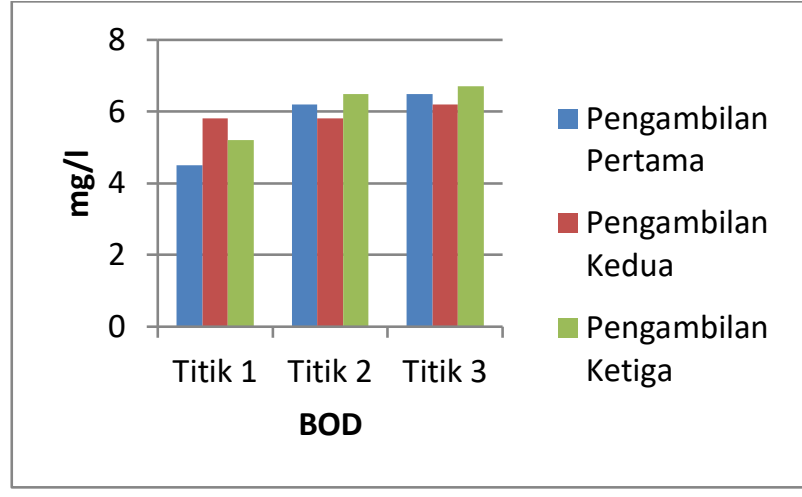

Gambar 8. Hasil pengukuran BOD

\section{- Chemical Oxygen Demand (COD)}

Berdasarkan hasil pengukuran COD, didapatkan nilai COD berkisar antara 7,6-14,7 mg/l (Gambar 9). Sesuai dengan baku mutu PP Nomor 22 Tahun 2021, bahwa nilai COD untuk kategori perairan kelas 2 adalah $25 \mathrm{mg} / \mathrm{l}$, sehingga dapat dikatakan nilai COD pada perairan ini masih memenuhi baku mutu. Nilai konsentrasi COD yang semakin tinggi juga menindikasikan bahwa suatu perairan telah tercemar. Nilai COD umumnya lebih besar dibandingkan nilai COD. Hal ini disebabkan jumlah senayawa organic yang dapat dioksidasi secara kimiawi lebih besar jika dibandingkan secara biologis (Yulis, $d k k ., 2018$ ). Berdasarkan hasil pengukuran dapat dikatakan bahwa Sungai Bah Biak masih dapat mendukung kegiatan pertanian dan peternakan masyarakat, tetapi tidak layak lagi untuk dijadikan air minum.

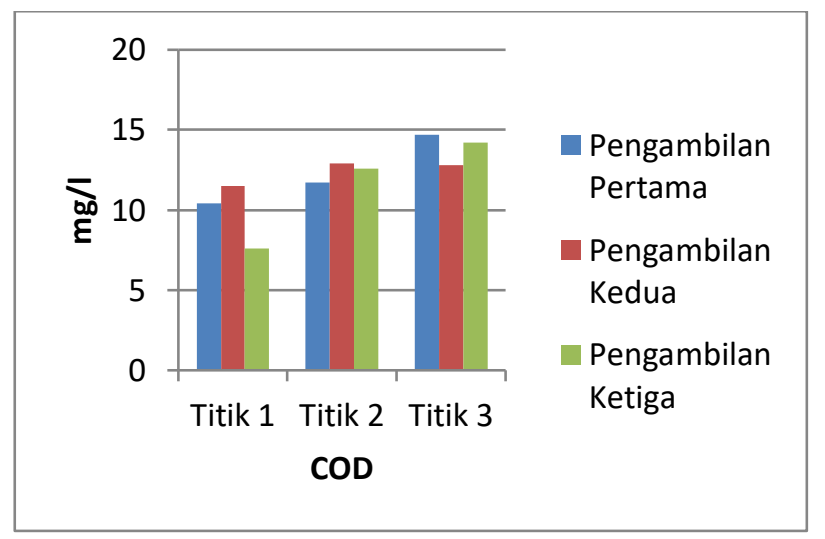

Gambar 9. Hasil pengukuran COD

\section{- Ammonia}

Kondisi kadar ammonia yang terukur adalah pada kisaran nilai 0,165-0,412 mg/l. Nilai ammonia pada pengambilan ketiga di bulan Agustus menunjukan nilai yang lebih tinggi dibandingkan bulan lainnya. Hal ini tentu sangat tidak diharapkan oleh pembudidaya ikan, terutama dengan jenis ikan yang sensitif terhadap perubahan ammonia tersebut. Sesuai dengan baku mutu berdasarkan PP No. 22 Tahun 2021 untuk kelas 2 bahwa nilai maksimal ammonia dalam perairan adalah $0,2 \mathrm{mg} / \mathrm{l}$, sehingga dapat dikatakan nilai ammonia yang diperoleh di Sungai Bah Biak ini tinggi dan menyebabkan pencemaran. Menurut Effendi (2013), kadar ammonia pada perairan alami umumnya di bawah $0,1 \mathrm{mg} / \mathrm{l}$. Kadar ammonia yang tinggi dapat mengindikasikan adanya limbah yang dibuang ke perairan baik dari limbah domestik maupun limpasan limbah pertanian. Hal ini juga dibuktikan dengan masih banyak aktivitas masyarakat yang berasal dari lahan pertanian dan juga pemukiman.

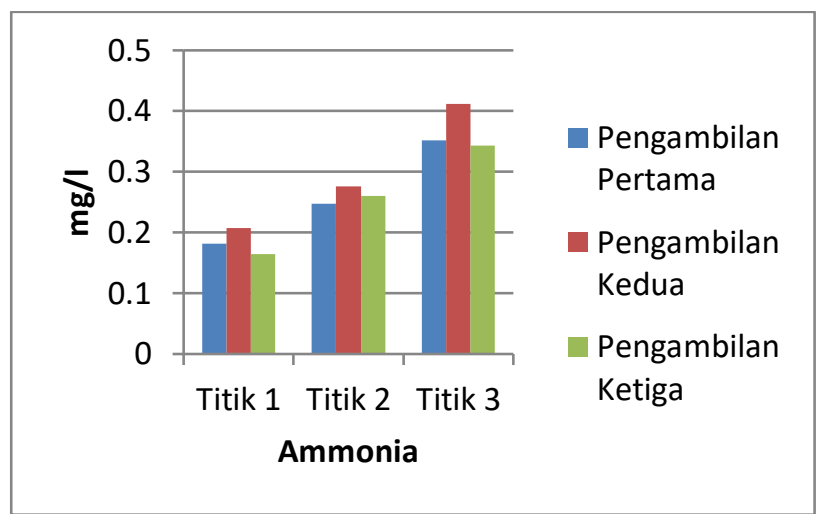

Gambar 10. Hasil pengukuran ammonia

\section{KESIMPULAN DAN SARAN}

Berdasarkan hasil pengukuran beberapa parameter kualitas air di Sungai Bah Biak maka dapat disimpulkan bahwa mayoritas parameter yang diteliti masih memenuhi baku mutu namun terdapat parameter yang telah melewati ambang baku mutu yaitu parameter BOD dan ammonia.

Beberapa saran yang dapat diberikan berdasarkan hasil penelitian adalah sebagai berikut:

a. Perlu pengawasan lebih ketat dari instansi terkait dalam hal pembuangan limbah domestik, pertanian dan peternakan yang dilakukan oleh masyarakat.

b. Perlu adanya sosialisasi atau penyuluhan kepada masyarakat sekitar sungai tentang sadar lingkungan. 
c. Perlu peninjauan dan evaluasi yang ketat sebelum pemberian izin pembangunan/pemanfaatan lahan sekitar sungai.

\section{DAFTAR PUSTAKA}

Dahuri, R. 2001. Pengelolaan Ruang Wilayah Pesisir dan Lautan Seiring Dengan Pelaksanaan Otonomi Daerah. Mimbar XVII(2): 139-171.

Djoharam, V., E. Riani, M. Yani. 2018. Analisis Kualitas Air dan Daya Tampung Beban Pencemaran Sungai Pesanggrahan di Wilayah Provinsi DKI Jakarta. Jurnal Pengerlolaan Sumberdaya Alam dan Lingkungan 8(1): 127133.

Effendi, H. 2003. Telaah Kualitas Air Bagi Pengelolaan Sumberdaya Air dan Lingkungan Perairan. Kanisius: Yogyakarta.

Effendi, H., A.A. Kristianiarso, E.M. Adiwilaga. 2013. Karakteristik Kualitas Air Sungai Cihideung, Kabupaten Bogor, Jawa Barat. Ecolab 7(2): 81-92.

Gasim, M.B., N.A. Khalid, H. Muhamad. 2015. The Influece of Tidal Activities on Water Quality of Paka River Terengganu, Malaysia. Malaysia Journal of Analytical Science 19(5): 979-990.

Hauer, F.R. \& W.R. Hill. 2007. Temperature, Light, and Oxygen. Methods in Stream Ecology (Second Edition): 103-117. https://doi.org/10.1016/B978-0123329080.50007-3

Idrus, S.W.A. 2014. Analisis Pencemaran Air Menggunakan Metode Sederhana Pada Sungai Jangkuk, Kekalik dan Sekarbela Kota Mataram. Paedagoria 10(2): 8-14.

Khairuddin, M. Yamin, A. Syukur. 2016. Analisis Kualitas Air Kali Ancar Dengan Menggunakan Bioindikator Makroinvertebrata. Jurnal Biologi Tropis 16(2): 10-22.

Khairunnas, K. \& M. Gusman. 2018. Analisis Pengaruh Parameter Konduktivitas, Resistivitas dan TDS Terhadap Salinitas Air Tanah Dangkal Pada Kondisi Air Laut Pasang dan Air Laut Surut di Daerah Pesisir Pantai Kota Padang. Jurnal Bina Tambang 3(4): 1751-1760.

Liyanage, C.P. \& K. Yamada. 2017. Impact of Population Growth on The Water Quality of Natural Water Bodies. Sustainability 2017(9): 1-14. doi:10.3390/su9081405.

Mainassy, M.C. 2017. Pengaruh Parameter Fisika dan Kimia Terhadap Kehadiran Ikan Lompa (Thryssa baelama Forsskal) di Perairan Pantai
Apui Kabupaten Maluku Tengah. Jurnal Perikanan Universitas Gadjah Mada 19 (2). 61-66.

Mannaulina, C.D. 2018. Kajian Kualitas Air Sungai Bah Kapul di Kota Pematangsiantar. Tesis. Fakultas Ilmu Sosial. Universitas Negeri Medan.

Mustika, R. 2017. Dampak Degradasi Lingkungan Pesisir Terhadap Konsisi Ekonomi Nelayan: Studi Kasus Desa Takisung, Desa Kuala Tambangan, Desa Tabanio. Dinamika Maritim 6(1): 28-34.

Notonagoro, A.G., S.R.P, Sitorus, S.D. Tarigan. 2019. Perubahan Penggunaan Lahan dan Keterkaitannya Dengan Kondisi Hidrologi DAS Ketahun Bagian Hulu, Kabupaten Lebong. Tesis. Institut Pertanian Bogor.

Pamungkas, M.T.O.A. 106. Studi Pencemaran Limbah Cair Dengan Parameter BOD dan $_{5} \mathrm{pH}$ di Pasar Ikan Tradisional dan Pasar Modern di Kota Semarang. Jurnal Kesehatan Masyarakat 4(2): 166-175.

Peraturan Pemerintah Republik Indonesia Nomor 22 Tahun 2021 Tentang Penyelenggaraan Perlindungan dan Pengelolaan Lingkungan Hidup.

Permatasari, R., Arwin, D.K. Natakusumah. 2017. Pengaruh Perubahan Penggunaan Lahan Terhadap Rezim hidrologi DAS (Studi Kasus: DAS komering). Jurnal Teknik Sipil 24(1): 9198. DOI: 10.5614/jts.2017.24.1.11.

Prasetyawan, I.B., L. Maslukah, A. Rifai. 2017. Pengukuran Sistem Karbondioksida $\left(\mathrm{CO}_{2}\right)$ Sebagai Data Dasar Penentuan Fluks Karbon di Perairan Jepara. Buletin Oseanografi Marina 16(1): 9-16.

Pratiwi, N.T.M., S. Hariyadi, D.I. Kiswari. 2017. Struktur Komunitas Perifiton di Bagian Hulu Sungai Cisadane, Kawasan Taman Nasional Gunung Halimun Salak, Jawa Barat. Jurnal Biologi Indonesia 13(2): 289-296.

Salmin. 2005 Oksigen Terlarut (DO) dan Kebutuhan Oksigen Biologi (BOD) Sebagai Salah Satu Indikator Untuk Menentukan Kualitas Perairan. Oseana XXX(3): 21-26.

Sanger, Y.Y.J., J. E.X. Rogi, J. Rombang. 2016. Pengaruh Tipe Tutupan Lahan Terhadap Iklim Mikro di Kota Bitung. Agri-SosioEkonomi 12(3A): 105-116.

Sembiring, H. 2008. Keanekaragaman dan Distribusi udang Serta Kaintannya Dengan Faktor Fisik Kimia di Perairan Pantai Labu Kabupaten Deli Serdang. Tesis. Sekolah Pascasarjana universitas Sumatera Utara. 
Sihombing, P.C. 2018. Pengaruh Perbedaan Suhu Air Terhadap Pertumbuhan dan Kelangsungan hidup Ikan Nilai (Oreochromis niloticus). Skripsi. Fakultas Pertanian Program Studi Manajemen Sumberdaya Perairan, Universitas Sumatera Utara.

Silalahi, M.V. 2020. Analisis Kualitas Air Sungai Bah Bolon di Kota Pematangsiantar. Jurnal Biosains 6(3): 66-71.

Simanjuntak, M. 2007. Oksigen Terlarut dan Apparent Oxygen Utilization di Perairan Teluk Klabat, Pulau Bangka. Ilmu Kelautan 12(2): 59-66.

Sugianti, Y. \& L.P. Astuti. 2018. Respon Oksigen Terlarut Terhadap Pencemaran dan Pengaruhnya Terhadap Keberadaan Sumberdaya Ikan di Sungai Citarum. Jurnal Teknologi Lingkungan 19(2): 203-211.

Utami, N.D. \& A. Suprayogi. 2014. Kajian Debit Banjir Akibat Perubahan Penggunaan Lahan di
Sub DAS Belik, Daerah Istimewa Yogyakarta. Jurnal Bumi Indonesia 3(3): 1-10.

Yogafanny, E. 2015. Pengaruh Aktivitas Warga di Sempadan Sungai Terhadap Kualitas Air Sungai Winongo. Jurnal Sains dan Teknologi Lingkungan 7(1): 41-50.

Yohannes, B., S. W. Utamo, H. Agustina. 2019. Kajian Kualitas Air Sungai dan Upaya Pengendalian Pencemaran Air (Studi di Sungai Krukut, Jakarta Selatan). Indonesian Journal of Environmental Education and Management 4(2): $\quad$ 136-155. DOI: doi.org/10.21009/jgg.042.05.

Yulis, P.A.R., Desti, A. Febliza. 2018. Analisis Kadar DO, BOD, dan COD Air Sungai Kuantan Terdampak Penambangan Emas Tanpa Izin. Jurnal Bioterdidik Wahana Ekspresi Ilmiah 6(3). 